Atıf/How to cite: İpek, V. A., \& Çokuysal, B. (2018). NBPT kaplamalı ürenin buğday ve mısırda etkinliğinin belirlenmesi. Ege Üniv. Ziraat Fak. Derg., 2018, 55 (4):407-412. DOI: 10.20289/zfdergi.413711

\section{Araştırma Makalesi (Research Article)}

Volkan Ahmet IPEK ${ }^{1}$

Burçin ÇOKUYSAL ${ }^{1}$ ${ }^{1}$ Ege Üniversitesi, Ziraat Fakültesi, Toprak Bilimi ve
Bitki Besleme Anabilim Dalı Bornova-Izmir

sorumlu yazar / correspondence:

Volkan IPEK, volkan_ipek@hotmail.com.tr

\section{Anahtar sözcükler:}

Ekmeklik buğday, silajlık mısır, NBPT, üre, verim.
Ege Üniv. Ziraat Fak. Derg., 2018, 55 (4):407-412 DOI: $10.20289 /$ zfdergi.413711

\title{
NBPT Kaplamalı Ürenin Buğday ve Mısırda Etkinliğinin Belirlenmesi
}

Determination of the Efficiency of NBPT-Coated Urea in Wheat and Corn

\author{
Alınış (Received): 09.04.2018 Kabul tarihi (Accepted): 16.04.2018
}

Öz

Amaç: Bu çalışma NBPT kaplamalı üre azotunun buğday (Triticum aestivum) ve mısırda (Zea mays) etkinliğinin denenmesi amacıyla İzmir İli Aliağa İlçesi'nde ve İzmir İli Tire İlçesi'ne bağlı Derebaşı Köyü'nde olmak üzere iki farklı lokasyonda kurulmuştur.

Materyal ve Metot: İzmir İli Aliağa İlçesinde yürütülen denemede Ziyabey 98 ekmeklik buğday (Triticum aestivum) çeşidi İzmir İli Tire İlçesi Derebaşı Köyünde yürütülen denemede ise Limagrain 30,709 silajlık mısır (Zea mays) çeşidi kullanılmıştır. Denemeler 2014-2015 yetiştirme sezonunda tesadüf blokları deneme desenine göre 4 tekerrür olacak şekilde kurulmuştur. Çalışmada NBPT kaplı üre azotunun ekmeklik buğday bitkisinde tam doz ve yarım doz şeklinde uygulanarak başak boyu, başakta tane sayısı, azot içeriği ve toplam verim üzerine olan etkileri, silajlık mısır bitkisinde ise tam doz şeklinde uygulanarak koçan uzunluğu, sap kalınlığı, koçanda tane sayısı, azot içeriği ve toplam verim üzerine olan etkileri araştırılmıştır.

Bulgular: Çalışmada, NBPT kaplı üre azotunun ekmeklik buğday bitkisinde tam doz ve yarım doz şeklinde uygulanarak başak boyu, başakta tane sayısı, azot içeriği ve toplam verim üzerine artırıcı etkide bulunduğu ayrıca NBPT kaplı üre azotunun silajlık mısır bitkisinde ise koçan uzunluğu, sap kalınlığı, koçanda tane sayısı, azot içeriği ve toplam verim üzerinde artırıcı etkide bulunduğu saptanmıştır.

Sonuç: Araştırma sonuçlarına göre, NBPT kaplı üre azotunun ekmeklik buğday ve silajlık mısır bitkileri üzerinde verim ve verime bağlı öğelerde önemli artışlar sağladığı belirlenmiştir.

\section{ABSTRACT}

Objective: This study is placed in two different locations as Aliaga County and Tire County of the city of Izmir with the aim of the trial of efficiency of NBPT-coated urea nitrogen in wheat and corn.

Material and Methods: In the trial run in Aliaga County, Ziyabey used 98 kinds of bread wheat while in the one run in the village of Derebasi of Tire county, Limagrain used 30,709 kinds of silage corn. The trials are located as 4 repeats according to trial patterns of randomized blocks in the season of 20142015. In the study, anther height, anther grain size, nitrogen content and the impacts on total yield by applying NBPT-coated urea nitrogen in the plant of bread wheat in exact and half doses are researched while in the plant of silage corn, stem length, stem thickness, grain size in a stem, nitrogen content and the impacts on total yield in exact doses are analyzed.

Results: In the study, NBPT-coated urea nitrogen enables increases anther height, anther grain size, nitrogen content and the impacts on total yield in bread wheat. Besides, NBPT-coated urea nitrogen enables increases stem length, stem thickness, grain size in a stem, nitrogen content and the impacts on total yield in the plant of silage corn.

Conclusion: According to the research results, it has been determined that NBPT-coated urea nitrogen enables dramatic increases in the yield and the elements related to productiveness in bread wheat and silage corn. 


\section{GíRiş}

Insan beslenmesinde temel hammadde olan tahıllar, hayvan beslenmesinde ve endüstride de yaygın biçimde kullanılır. Buğday tahıllar içerisinde ilk kültüre alınan, dünyada ekim alanı, üretimi ve tüketimi en fazla olan, adaptasyon kabiliyeti yüksek bir kültür bitkisidir. Sahip olduğu büyük adaptasyon yeteneği sayesinde her türlü iklimde ve yörede yetiştirilebilme üstünlüğü buğdayı stratejik öneme sahip bir bitki haline getirmektedir. Bu anlamda, artan besin maddeleri ihtiyacını karşılama yönünden tahıllar ve özelikle de buğday büyük önem taşır.

Buğday da birim alan veriminin arttırılması için öncelikle ekolojiye uygun iyi bir çeşit seçimi esastır. Belirlenen bu çeşidin iyi tohumluğu, ekileceği tarlanın hazırığı, ekim zamanı, yöntemi, tohum miktarı, gübreleme, bakım, hasat ve harman verim üzerinde etkili unsurlardır. Ancak, birim alana ekilecek tohum miktarı ile gübreleme buğday verimini üzerine etkili önde gelen iki faktördür. Tarımsal üretim, ülkelerin ekonomik gelişmişlikleri ve insan refahının gelişmesi sonucu artan ve değişen talep özellikleri doğrultusunda değişmiştir. Bunların başında maliyeti düşürmek için mekanizasyon kullanımı ve verimliliği artırmak için kimyasal girdi kullanımı gelmektedir (Bayramoğlu ve Gündoğmuş, 2010). Bununla birlikte gübrelerin verimlilik artışındaki payı koşullara göre değişse de, genel olarak \% 50 civarında olduğu ifade edilmektedir.

Bitkiler için yaşamsal öneme sahip olan azot mutlak gerekli besin elementlerinin ilk sırasında yer almaktadır.

Azotlu gübre uygulamasının sıklığı ve zamanı ekmeklik buğdayın (Triticum aestivum) dane ve ot verimi ile kalitesini, ürün sonrası toprak profilinde bakiye nitrat (NO3) formundaki azot konsantrasyonunu ve dağılımını etkilemektedir (Boman ve ark.,1995).

Enönemlibuğdayyetiştirmetekniğiuygulamalarından birisi olan azotlu gübreleme, kışlık buğdayın optimum vejetatif ve generatif gelişmeyi gösterebilmesi için, azota olan ihtiyacı diğer besin maddelerine oranla daha yüksektir ve bu ihtiyaç genellikle azot uygulaması ile karşılanmakta, azotun eksikliği ve fazlalığında verim ve verim komponentlerinde önemli azalmalar olmakta, azot fazlalığında ise buğday vejetatif olarak fazla gelişmekte, çok sayıda kardeş oluşturmakta, yatma meydana gelmekte ve verim düşmektedir (Akkaya,1994).

Dünyada 2014 üretim yılı verilerine göre buğdayda toplam, 708 milyon ton ürün elde edilmiştir (IGC,2014). Ülkemizde ise 2015 yılında 7,91 milyon ha alanda buğday ekimi yapılmış ve verim 22,6 milyon ton olarak gerçekleşmiştir (TÜiK, 2015).

Türkiye tarımında önemli bir paya sahip olan mısır (Zea mays) ise gerek doğrudan insan beslenmesinde gerekse nişasta, glikoz, yağ ve yem sanayinde hammadde olarak kullanılmaktadır. Dünya nüfusunun, enerji ve protein ihtiyacının büyük bir kısmını karşılayan tahıllar içerisinde mısırın ayrı bir önemi vardır. Bir sıcak iklim bitkisi olan mısır, sahip olduğu çeşit zenginliği ve yüksek adaptasyon kabiliyeti nedeni ile dünyanın hemen her yerinde tarımı yapılabilen bir kültür bitkisidir (Koçak, 1987).

Ülkemizde hayvancılığın gelişmesine paralel olarak artan yem talebine bağlı olarak mısır talebi de artmaktadır. Mısır tanesi çok iyi bir enerji kaynağı olup, nişasta yönünden zengin olması ve nişastanın hazmolabilirlik derecesinin yüksekliği beslenme değerini artırmaktadır. Mısır ayrıca, yeşil olarak ve silaj olarak da hayvan beslenmesinde kullanılan önemli bir kaba yemdir. Başka bir anlatımla, mısır üretiminin büyük bölümü hayvan yemi olarak kullanılmaktadır (Kırtok, 1998).

Mısır silajı, dünyada üretilen en ekonomik ve en yaygın kaba yem olup, Amerika Birleşik Devletleri, Hollanda, Almanya ve Fransa gibi ülkelerde proteince zenginleştirilerek sığır besiciliğinde çok yoğun olarak kullanılmaktadır (Alçiçek ve Karaayvaz, 2003).

Üreticilerimiz kaba yem sıkıntısının yaşandığı dönemlerde genelde hayvanlarını zorunlu olarak, besin maddesi içeriği düşük tahıl samanı ile beslemektedir. Fakat son yıllarda üreticilerin bilinçlenmesi ile taze ve su bakımından zengin, karbonhidrat içeriği yüksek bitkilerinin parçalanması ile elde edilen ve silaj adı verilen kaba yemler tercih edilmeye başlanmıştır (Orak ve İptaş 1999).

Dünyada mısır üreten 166 ülke arasında Türkiye, mısır ekim alanı bakımından 41. toplam üretim bakımından 26. ve birim alandan alınan verim açısından 21. ülke durumundadır (FAO, 2013). Türkiye 2015 yılı tarım istatistiklerine göre mısır, toplam tahıllar içerisinde 1 milyon 98 bin dekarlık ekim alanı, 26 milyon tonluk üretimi ile buğday ve arpadan sonra 3.sırada yer almaktadır ve ortalama mısır verimi 5700 kg/da'dır ( TUiK 2015).

Mısır bitkisinin birim alanda kısa sürede ürettiği kuru madde miktarı, küçük taneli hububatlara göre fazla olduğundan, topraktan daha fazla miktarda $N, P$ ve $K$ almaktadır. Bu nedenle, mısır gübrelemesinde ilk sırayı azot elementi almaktadır. Bitkinin azottan yararlanmasını toprak tekstürü, toprak nemi, toprak profilinden yıkanması, organik madde içeriği, diğer bitki besin elementlerinin topraktaki düzeyleri etkilemektedir.

Genel olarak ürün artışında gübreden beklenilen etkinin artması için bölgenin iklim ve toprak özellikleri, bitkinin cinsi ve verilecek gübrenin formu oldukça önemlidir (Atak ve ark., 2005).

Azotun bitkiler üzerindeki önemi yukarıda da vurgulandığı üzere azotlu gübrelerin toprağa verilme zamanının belirlenmesinde göz önüne alınacak konulardan birisi de azot kaybıdır.

Gübreleme ile toprağa kazandırılan üre azotunun yaklaşık \%30'u buharlaşma ile kaybolmaktadır. Gübreleme ile toprağa kazandırılan bu azot toprakta bulunan üreaz enziminin etkisiyle amonyak $\left(\mathrm{NH}_{3}\right)$ gazı şeklinde kaybolmaktadır. Bu kayıpların engellenmesi ve bitkinin kullanabileceği şekilde toprakta tutulmasının gerek üreticiye getireceği ekonomik avantaj gerekse 
bitkinin ihtiyaç duyduğu azot miktarının kayıp olmadan karşılanması ihtiyacı geleneksel gübrelerin yeni nesil gübreler ile etkileşimine sebep olmuştur.

Bu bağlamda bu araştırma; akıllı gübre olarak da adlandırabileceğimiz standart üre azotunun NBPT (N-(nbutil) thiophosphoric triamide) kaplama maddesi ile kaplanmasıyla üreaz enziminin etkisini ortadan kaldırarak bitkilerin azot ihtiyacını maksimum oranda $\mathrm{NH}_{3}$ gazı şeklinde kayıp olmadan karşılamak adına yürütülmüştür.

\section{MATERYAL ve METOT}

\section{Materyal}

$\mathrm{Bu}$ denemeler 2014-2015 yetiştirme sezonunda buğdayda 120 gün süreyle İzmir İlinin Aliağa ilçesinde, mısırda ise 110 gün süreyle İzmir İlinin Tire İlçesine bağlı Derebaşı köyünde yürütülmüştür.

Deneme alanlarının sırasıyla denizden yükseklikleri Aliağa İlçesi için 2m, Tire İlçesine bağlı Derebaşı köyü için ise $96 \mathrm{~m}$ olup sırasıyla Aliağa ilçesi $38^{\circ} 50^{\prime} 31,8^{\prime \prime}$ enlem ve $26^{\circ} 58^{\prime} 50,8^{\prime \prime}$ boylamı, Tire ilçesine bağlı Derebaşı köyü ise $38^{\circ} 09^{\prime} 22,2^{\prime \prime}$ enlem ve $27^{\circ} 46^{\prime} 23,1^{\prime \prime}$ boylamı arasında bulunmaktadır.

İzmir İli Aliağa İlçesinde yürütülen denemede Ziyabey 98 ekmeklik buğday (Triticum aestivum) çeşidi kullanılmıştır. Kullanılan çeşit; kılçıklı, beyaz başaklı, başaklar orta sık ve uca doğru sivridir. Orta erkenci, yatmaya, sarı pasa ve septoria'ya dayanıklı olup kara pasa ise hassastır ve yaklaşık hasat süresi 120 gündür.

İzmir İli Tire İlçesi Derebaşı Köyünde yürütülen denemede Limagrain 30,709 silajlık mısır (Zea mays) çeşidi kullanılmıştır. Kullanılan çeşit; orta erkenci, silaj verim potansiyeli yüksek, güçlü sap ve kök sistemine sahip bir çeşit olup yaklaşık hasat süresi 110 gündür.

\section{Metot}

Deneme 2014-2015 yetiştirme sezonunda İzmir İli Aliağa İlçesinde ve İzmir ìli Tire İlçesine bağlı Derebaşı Köyü'nde tesadüf blokları deneme desenine göre 4 tekerrür olacak şekilde kurulmuştur. Aliağa İlçesinde yürütülen denemede ekmeklik buğday tohumlarının ekimi 05.12.2014 tarihinde $15.000 \mathrm{~m}^{2}$ alana elle serpme yöntemiyle yapılmış olup Tire İlçesine bağlı Derebaşı Köyünde yürütülen denemede ise silajlık mısır tohumları mibzer yardımıyla sıra arası $16 \mathrm{~cm}$, sıra üzeri ise $70 \mathrm{~cm}$ olacak şekilde 15.04 .2015 tarihinde $12.000 \mathrm{~m}^{2}$ alana ekimi yapılmıştır.

\section{Analiz ve Ölçümler}

\section{Buğday denemesinde yapılan analiz ve ölçümler}

Başak boyu (cm): Her parselden tesadüf olarak seçilen 10 örnek başak, ilk başakçığın bağlı olduğu boğumdan, kılçık hariç son başakçık ucuna kadar olan mesafe ölçülmüştür.

Başakta tane sayısı (adet): Her parselden tesadüf olarak seçilen 10 örnek başaktaki taneler sayılarak hesaplanmıştır.

Azot içeriği: Hasat edilen her parselden alınan bitki örnekleri kurutularak öğütüldükten sonra Kjeldahl aygıtı kullanılarak azot içerikleri tespit edilmiştir (Kacar 1984).

Toplam verim (tonftasat edilen deneme parsellerinin tartılmasıyla elde edilmiştir.

Silajlık mısır denemesinde yapılan analiz ve ölçümler

Koçan uzunluğu (cm): Hasat döneminde, her parselden rastgele seçilen 10 bitkide, koçan uzunlukları ölçülmüştür.

Sap kalınlığı (cm): Hasat döneminde, her parselden rastgele seçilen 10 bitkinin, sap kalınlığı toprak yüzeyinin $10 \mathrm{~cm}$ üzerinden kumpasla ölçülmüştür (Keskin,2001).

Koçanda tane sayısı (adet): Her parselden tesadüf olarak seçilen 10 örnek koçandaki taneler sayılarak hesaplanmıştır.

Azot içeriği: Hasat edilen her parselden alınan bitki örnekleri kurutularak öğütüldükten sonra Kjeldahl aygıtı kullanılarak azot içerikleri tespit edilmiştißkacar 1984).

Toplam verim (tonftasat edilen deneme parsellerinin tartılmasıyla elde edilmiştir.

\section{ARAŞTIRMA BULGULARI \\ Ekmeklik Buğday}

Başak boyu (cm): Uygulanan farklı gübrelerin başak boyu üzerine etkinliği istatistikî olarak \%5 düzeyde önemli olarak bulunmuştur. $\mathrm{Bu}$ etkinliğin hangi faktörde ya da hangi gübrede başak boyu üzerine daha etkili olduğunu görebilmek amacıyla yapılan LSD testinde ilk farklı grubu NBPT-Tam doz uygulamasının aldığı belirlenmiştir. Bununla birlikte NBPT-Yarım doz uygulaması NBPT-Tam doz ve Üre arasında bir etki göstermiş ve ikinci grubu oluşturmuştur, üçüncü grubu ise Üre uygulaması oluşturmuştur. Buğdayda etkinliği denenen farklı azotlu gübre uygulamalarının başak boyuna etkisi Çizelge 1. de gösterilmiştir.

Başakta tane sayısı (adet): Uygulanan farklı gübrelerin başak boyu üzerine etkinliği istatistikî olarak \% 5 düzeyde önemli olarak bulunmuştur. Bu etkinliğin hangi faktörde ya da hangi gübrede başakta tane sayısı üzerine daha etkili olduğunu görebilmek amacıyla yapılan LSD testinde ilk farklı grubu NBPT-Tam doz uygulamasının aldığı belirlenmiştir. Bununla birlikte NBPT-Yarım doz uygulamasıyla Üre uygulaması arasında belirgin bir fark olamamakla birlikte bu uygulamalar ikinci grubu oluşturmuştur. Buğdayda etkinliği denenen farklı azotlu gübre uygulamalarının başak tane sayısına etkisi Çizelge 1. de gösterilmiştir.

Azot içeriği: Uygulanan farklı gübrelerin azot içeriğine olan etkisi istatistikî olarak \%1 düzeyde önemli olarak bulunmuştur. Bu etkinliğin hangi faktörde ya da hangi gübrede azot içeriği üzerine daha etkili olduğunu görebilmek amaciyla yapılan LSD testinde NBPT-Tam doz ve NBPT-Yarım doz uygulamalarının arasında belirgin bir 
fark görülmemiş ve bu iki grubun ilk grubu oluşturduğu belirlenmiştir. Bununla birlikte Üre uygulamasının da ikinci grubu oluşturduğu belirlenmiştir. Buğdayda etkinliği denenen farklı azotlu gübre uygulamalarının azot içeriğine etkisi Çizelge 1. de gösterilmiştir.

Toplam verim (ton): Uygulanan farklı gübrelerin toplam verime olan etkisi istatistikî olarak \%1 düzeyde önemli olarak bulunmuştur. Bu etkinliğin hangi faktörde ya da hangi gübrede toplam verim üzerine daha etkili olduğunu görebilmek amacıyla yapılan LSD testinde NBPT-Tam doz uygulamasının ilk farklı grubu oluşturduğu, NBPT-Yarım doz uygulamasının ikinci farklı grubu, Üre uygulamasının ise 3. farklı grubu oluşturduğu belirlenmiştir. Buğdayda etkinliği denenen farklı azotlu gübre uygulamalarının toplam verime etkisi Çizelge 1. de gösterilmiştir.

Çizelge 1. Farklı Azot Form ve Dozlarının Buğdayda Çeşitli Parametrelere Etkisi

Table 1. The Effect of Different Nitrogen Forms and Doses on Various Parameters in Wheat

\begin{tabular}{|c|c|c|c|c|}
\hline Farklı Azot Formları Ve Dozları & Başak Boyları Ortalamaları(cm) & Başakta Tane Sayısı & Azot İçeriği & Toplam Verim \\
\hline NBPT Tam Doz & $8,600(a)$ & $45,500(a)$ & $2,006(a)$ & $356,000(a)$ \\
\hline NBPT Yarım Doz & $8,150(a b)$ & $41,500(b)$ & $1,980(a)$ & $332,000(b)$ \\
\hline Üre Tam Doz & $8,000(b)$ & $40,750(b)$ & $1,729(b)$ & $311,000(c)$ \\
\hline LSD Değeri & (\%5) 0,451 & (\%5) 3,498 & (\%1) 0,175 & (\%1) 10,043 \\
\hline
\end{tabular}

\section{Mısır}

Koçan Uzunluğu (cm): Uygulanan farklı gübrelerin koçan uzunluğu üzerine etkinliği istatistikî olarak \%5 düzeyde önemli olarak bulunmuştur. Bu etkinliğin hangi faktörde ya da hangi gübrede koçan uzunluğu üzerine daha etkili olduğunu görebilmek amacıyla yapılan LSD testinde ilk farklı grubu NBPT-Tam doz uygulamasının aldığı belirlenmiştir. İkinci farklı grubu da Üre uygulamasının oluşturduğu belirlenmiştir. Mısırda etkinliği denenen farklı azotlu gübre uygulamalarının koçan uzunluğuna etkisi Çizelge 2. de gösterilmiştir.

Sap kalınlığı (cm): Uygulanan farklı gübrelerin sap kalınlığı üzerine etkinliği istatistikî olarak \%1 düzeyde önemli olarak bulunmuştur. Bu etkinliğin hangi faktörde ya da hangi gübrede sap kalınlığı üzerine daha etkili olduğunu görebilmek amacıyla yapılan LSD testinde ilk farklı grubu NBPT-Tam doz uygulamasının aldığı belirlenmiştir. İkinci farklı grubu da Üre uygulamasının oluşturduğu belirlenmiştir. Mısırda etkinliği denenen farklı azotlu gübre uygulamalarının sap kalınlığına etkisi Çizelge 2. de gösterilmiştir.

Koçanda tane sayısı: Uygulanan farklı gübrelerin koçanda tane sayısı üzerine etkinliği istatistikî olarak \%1 düzeyde önemli olarak bulunmuştur. Bu etkinliğin hangi faktörde ya da hangi gübrede koçanda tane sayısı üzerine daha etkili olduğunu görebilmek amacıyla yapılan LSD testinde ilk farklı grubu NBPT-Tam doz uygulamasının aldığı belirlenmiştir. İkinci farklı grubu da Üre uygulamasının oluşturduğu belirlenmiştir. Mısırda etkinliği denenen farklı azotlu gübre uygulamalarının koçanda tane sayısına etkisi Çizelge 2. de gösterilmiştir.

Azot içeriği: Uygulanan farklı gübrelerin azot içeriği üzerine etkinliği istatistikî olarak \%5 düzeyde önemli olarak bulunmuştur. Bu etkinliğin hangi faktörde ya da hangi gübrede azot içeriği üzerine daha etkili olduğunu görebilmek amacıyla yapılan LSD testinde ilk farklı grubu NBPT-Tam doz uygulamasının aldığı belirlenmiştir. İkinci farklı grubu da Üre uygulamasının oluşturduğu belirlenmiştir. Mısırda etkinliği denenen farklı azotlu gübre uygulamalarının azot içeriğine etkisi Çizelge 2. de gösterilmiştir.

Toplam verim (ton): Uygulanan farklı gübrelerin toplam verim üzerine etkinliği istatistikî olarak \%1 düzeyde önemli olarak bulunmuştur. Bu etkinliğin hangi faktörde ya da hangi gübrede toplam verim üzerine daha etkili olduğunu görebilmek amacıyla yapılan LSD testinde ilk farklı grubu NBPT-Tam doz uygulamasının aldığı belirlenmiştir. İkinci farklı grubu da Üre uygulamasının oluşturduğu belirlenmiştir. Mısırda etkinliği denenen farklı azotlu gübre uygulamalarının toplam verime etkisi Çizelge 2 . de gösterilmiştir.

Çizelge 2. Farklı Azot Form ve Dozlarının Mısırda Çeşitli Parametrelere Etkisi

Table 2. The Effect of Different Nitrogen Forms and Doses on Various Parameters in Maize

\begin{tabular}{|l|c|c|c|c|c|}
\hline Farklı Azot Formları Ve Dozları & Koçan Uzunluğu (cm) & Sap Kalınlığı (cm) & Koçanda Tane Sayısı & Azot İ̧ceriği & Toplam Verim \\
\hline NBPT Tam Doz & $28,450(a)$ & $4,302(a)$ & $774,750(a)$ & $1,456(a)$ & $7,000(a)$ \\
\hline Üre Tam Doz & $25,550(b)$ & $2,545(b)$ & $601,750(b)$ & $1,301(b)$ & $6,000(b)$ \\
\hline LSD Değeri & $(\% 5) 2,205$ & $(\% 1) 0,690$ & $(\% 1) 21,194$ & $(\% 5) 0,143$ & $(\% 1) 0,287$ \\
\hline
\end{tabular}


NBPT Kaplamalı Ürenin Buğday ve Mısırda Etkinliğinin Belirlenmesi

\section{SONUÇ}

Elde edilen sonuçlar doğrultusunda NBPT kaplı Üre gübresinin geleneksel Üre gübresine oranla incelenen kriterlerde artırıcı bir etki gösterdiği görülmektedir. Bu sonuçlar doğrultusunda NBPT kaplı Üre üreticiye önerilebilir.
Ancak üretici bazında düşünüldüğünde gübreleme materyalinin etkinliği kadar ekonomik analizlerinde önemli olduğu unutulmamalıdır. Önerilen dozların verim üzerine olan etkinlikleri ve gübre maliyetleri daha sonra yapılacak olan çalışmalarla ortaya konmalıdır. Bu çalışma farklı dozlarda ve farklı bitkilerde denenerek geliş̧irilmeli ve ekonomik dozları belirlenmelidir. 


\section{KAYNAKÇA/REFERENCES}

Akkaya, A. (1994). Buğday yetiştiriciliği. K. S. Ü. Genel Yayın No:1 Ziraat Fakültesi Genel Yayın No:1 Ders Kitapları Yayın No:1, Kahramanmaraş.

Alçiçek, A. ve Karaayvaz, K., (2003). Sığır besisinde mısır silajı kullanımı. Animalia, 203, 68-76s.

Anonim, FAO (2013). Food and Agriculture Organisation (Dünya Gıda Örgütü) http://www.fao.org (Erişim tarihi: 16 Haziran 2016)

Anonim, IGC (2014). International Grain Council (Uluslararası Tahıl Konseyi) http://www.igc.int (Erişim tarihi: 16 Haziran 2016)

Anonim, TÜiK (2015). Türkiye İstatistik Kurumu http://www.tuik.gov.tr (Erişim tarihi: 16 Haziran 2016)

Atak, M., Kaya M. \& Çiftçi, C.Y. (2005). Kızıltan-91 makarnalık buğday çeşidinde farklı azotlu gübreler ile uygulama şekillerinin verim ve bazı verim özelliklerine etkileri. Türkiye VI. Tarla Bitkileri Kongresi, Antalya. 5-9 Eylül 2005, Cilt I, 121-126s.

Bayramoğlu Z. \& Gündoğmuş E. (2010). Kurak iklim bölgelerinde organik tarım ve geleceği: Konya ili örneği. Internationol Conference on
Organic Agriculture in Scope of Environmental Problems, 37 February 2010 Famagusta, Cyprus Island.

Boman, R.K., R. L. Westerman, W.R. Raun, M.E. \& Jojola. (1995). Time of nitrogen application: Effects on winter wheat and residual soil nitrate department of agronomy. Soil Sci Soc Am J., 59, 1364-1369

Kacar, B., 1984. Bitki Besleme. Ankara Üni. Ziraat Fak. Yay. No: 899, 169175.

Keskin, S. 2001. Silajık Olarak Yetiştirilen Mısır Çeşitlerinde Bitki Sıklığının Verim ve Bazı Kompenentlere Etkisi Yüksek Lisans Tezi Selçuk Üniversitesi Fen Bilimleri Enstitüsü Tarla Bitkileri Anabilim Dalı. Konya.

Kırtok, Y., (1998). Mısır üretimi ve kullanımı. İstanbul: Kocaoluk Basım ve Yayınevi.

Koçak, A.N., (1987). Mısırın insan gıdası olarak önemi ve gıda endüstrisindeki yeri. türkiye mısır üretiminin geliştirilmesi. Problemler ve Çözüm Yolları Sempozyumu, Ankara.

Orak, A. \& İptaş, S., (1999). Silo yem bitkileri ve silaj. Ankara: Çayır Mera Amenajmanı ve Islahı Tarım ve Köyişleri Bakanlığı Tarımsal Üretim ve Geliştirme Genel Müdürlüğü. 49-69s. 